\title{
PEDAGONAL
}

Jurnal IImiah Pendidikan

http://journal.unpak.ac.id/index.php/pedagonal

\section{PENGGUNAAN METAFORA DALAM LIRIK LAGU EBIET G. ADE ALBUM PERJALANAN DAN IMPLIKASINYA PADA PEMBELAJARAN SEMANTIK BAHASA INDONESIA}

\author{
Tri Mahajani ${ }^{1{ }^{*},}$, Sri Rahayu Dwiastuti ${ }^{1}$, Mukodhas ${ }^{1}$ \\ ${ }^{1}$ Dosen Program Studi Pendidikan Bahasa dan Sastra Indonesia Fakultas Keguruan dan IImu \\ Pendidikan, Universitas Pakuan Jl. Pakuan No 1 Ciheuleut Bogor \\ *Korespondensi: trimahayani68@yahoo.co.id
}

\begin{abstract}
The research is aimed at describing the use of metaphors and finding out its implications in the song lyrics of Ebiet $G$. Ade from the album of Perjalanan to semantic learning of Indonesian language. The research uses analytical descriptive method with structuralism and propositional approaches. The technique of data collection is done by using note taking. The data of metaphor is analyzed using content analysis. The result shows that the album of Perjalanan from Ebiet $G$. Ade, consisting of nine songs, has 40 metaphors used to describe the thought and meaning about love among humans and their life covering happiness, sadness, and imagination. The use of metaphors is also to describe humans, life, feelings, suffering, sadness, and anxiety. Metaphors are also used for describing natural phenomena, society's life, social relations among humans and the description of the world. The description of humans and God relationship is also there, using complex metaphors. The analysis of metaphors use in the song lyrics of Ebiet in the album of Perjalanan can improve students' vocabulary enrichment and its meaning. Hence there is an implication to semantic learning of Indonesian language.
\end{abstract}

Keywords: Metaphors, Song lyrics, implication

\begin{abstract}
ABSTRAK
Penelitian ini bertujuan untuk mendiskripsikan penggunaan metafora dan mengetahui implikasi penggunaan metafora dalam lirik lagu Ebiet G. Ade di Album Perjalanan untuk pembelajaran Semantik Bahasa Indonesia. Penelitian ini menggunakan metode deskriptif analitik dengan ancangan strukturalisme dan proposisi. Teknik pengumpulan data penelitian ini dilakukan melalui teknik pencatatan dengan tahapan langkah-langkah pengumpulan data. Sedangkan teknik penganalisisan data metafora dalam lirik lagu menggunakan teknik analisis isi. Hasil penelitian ini menunjukkan bahwa dalam album Perjalanan Ebiet G. Ade, yang terdiri dari sembilan lagu memiliki 40 metafora yang digunakan untuk menggambarkan pemikiran dan pemaknaan tentang cinta dan percintaan antar insan dalam kehidupan manusia yang meliputi kebahagiaan, kesedihan, angan-angan. Penggunaan metafora juga untuk menggambaran tentang manusia, hidup, dan kehidupan meliputi perasaan, penderitaan, kesedihan, keresahan. Metafora digunakan juga untuk menggambarkan gejala alam, kehidupan masyarakat, gejolak sosial yang ada dalam masyarakat, penggambaran tentang dunia. Penggambaran hubungan manusia dengan Tuhan juga diungkapkan dalam bentuk metafora-metafora yang rumit. Analisis penggunaan metafora dalam lirik lagu Ebiet album Perjalanan dapat menambah pengetahuan tentang kosa kata dan makna sehingga dapat diimplikasikan pada pembelajaran Semantik Bahasa Indonesia.
\end{abstract}




\section{PENDAHULUAN}

Penelitian penggunaan metafora dalam lirik lagu Ebiet G. Ade Album Perjalanan dilatarbelakangi oleh banyaknya kata atau frasa yang digunakan dalam lirik-lirik lagu untuk melukiskan atau menggambarkan sesuatu Kata atau frasa yang digunakannya, makna sebenarnya berbeda dengan makna yang terdapat pada konteks lagu tersebut. Pengungkapan makna dari lagu tidak langsung merujuk pada rujukan semantiknya, sehingga tidak mudah untuk memahami makna dari lirik-lirik lagunya. Namun, penggunaan metafora dalam lagu dapat memperindah syair lagu dan pemahaman tentang makna tentang metafora akan memperkaya kosakata

Dalam lagu yang diciptakannya, Ebiet G. Ade menggunakan banyak menggunakan bentuk bahasa yang puitis dan indah, salah satunya dalam lirik lagu album Perjalanan. Moko Awee (2007) mengatakan bahwa lagu merupakan perpaduan antara unsur musik yang terdiri dari jenis irama dan melodi, serta unsur lirik lagu. Unsur musik ini dapat dikatakan penguat lirik lagu, tetapi juga bisa dilihat dari segi jenis irama dan melodinya. Dengan demikian, lirik lagu memiliki kaitan dengan unsur yang membangunnya. Dilihat dari pengimajinasian, Ebiet $\mathrm{G}$. Ade banyak mengungkapkannya dalam bentuk metafora. untuk menggambarkan suatu objek. .Metafora adalah persamaan sifat antara dua objek. la merupakan pengalihan semantik berdasarkan kemiripan persepsi makna. Kata putri malam untuk bulan ( Gorys Keraf , 2000) Bulan bermakna benda langit yang mengitari bumi, bersinar pada malam hari karena mengitari bumi. Bulan dimetaforakan dengan ungkapan putri malam karena putri bermakna wanita, dan wanita memiliki keindahan. Kesamaan presepsi makna tentang keindahan sehingga bulan dimetaforakan dengan putri malam.

Dalam metafora terlibat dua ide, yang satu adalah suatu kenyataan; sesuatu yang dipikirkan yang menjadi objek; dan yang satu merupakan perbandingan terhadap kenyataan tadi (Tarigan , 2013). Metafora ialah perbandingan yang implisit- tanpa kata seperti, sebagai,- di antara dua hal yang berbeda ( Moeliono dalam Tarigan, 2013).Pada kalimat Mina buah hati Edi, anak yang paling disayangi dimetaforakan dengan buah hati. Pada kalimat Ali mata keranjang, seorang laki-laki yang suka melihat-lihat wanita cantik dimetaforakan dengan mata keranjang. Pada bentuk metafora tersebut mempersamakan dua hal secara langsung tanpa kata seperti, bak,dsb. Jadi metafora merupakan penggunaan kata atau ungkapan bukan dalam arti sebenarnya. Penggunaan kata atau ungkapan itu untuk melukiskan atau menggambarkan sesuatu berdasarkan persamaan atau perbandingannya dengan bentuk lain. Dalam merperbandingkan atau mempersamakan ke dua hal tersebut dinyatakan secara implisit.

Penggunaan metafora untuk melukiskan atau menggambarkan sesuatu berdasarkan persamaan atau perbandingannya dengan bentuk lain, banyak digunakan dalam lirik lagu Ebiet G. Ade Dalam lirik lagunya, Ebiet G. Ade banyak menggunakan metafora untuk menggambarkan sesuatu yang hidup bagi makhluk hidup lainnya, yang hidup untuk yang mati, yang mati untuk yang hidup, atau yang mati untuk yang mati. Metafora digunakan untuk menceritakan tentang percintaan, manusia, perjalanan hidup, gejala sosial, gejala alam, juga hubungan manusia dengan Tuhan. Pengungkapan makna dari lirik lagu tidak langsung merujuk pada objek rujukan semantiknya sehingga sulit untuk memahami makna dari lirik-lirik lagu tersebut. Hal tersebut sejalan dengan pendapat Supriyanto (2014), gambaran pikiran adalah sebuah efek dalam pikiran yang menyerupai gambaran yang dihasilkan oleh penangkapan kita terhadap sebuah objek yang dapat dilihat oleh mata, syaraf penglihatan, dan daerah2 otak yang berhubungan.. Parera (2004)) mengemukakan metafora menjadi dan merupakan fenomena terpenting dalam hakekat pergeseran dan perubahan makna.

Makna-makna yang terdapat di dalam metafora dapat sebagai khasanah untuk memperkaya kosa kata. Metafora masuk dalam kajian Semantik Bahasa Indonesia. Cohen (dalam Jaszolt, 2002) mengatakan bahwa dari sudut pandang semantik, metafora terdiri dari dua macam makna yaitu makna kias dan makna yang dimaksudkan. Makna yang dimaksudkan dapat diungkapkan lewat serangkaian kata yang dapat diterapkan bersama pada lambang kias.

Berdasarkan pemikiran di atas, penelitian ini bertujuan untuk mendeskripsikan penggunaan metafora dan mengetahui implikasi penggunaan metafora dalam lirik lagu Ebiet G.Ade album Perjalanan pada pembelajaran Semantik Bahasa Indonesia.

\section{METODE PENELITIAN}

Penelitian ini merupakan penelitian kualitatif. Menurut Sugiono (2006) penelitian kualitatif digunakan untuk meneliti objek yang alamiah atau objek yang berkembang apa adanya.Penelitian ini menggunakan metode deskriptif analitik dengan ancangan strukturalisme dan proposisi. Ancangan strukturalisme digunakan untuk meneliti, memberikan, serta menerangkan segi-segi tertentu mengenai struktur bahasa berdasarkan fakta-fakta kebahasaan. Adapun ancangan proposisi 
memandang kalimat bukan dari sudut gramatikal saja melainkan dari sudut ilmu logika (Verhaar: 2015)

Data dalam penelitian ini berupa kalimat-kalimat dalam lirik lagu Ebiet G.Ade yang terdapat kata atau frasa penggunaan metafora. Sumber data penelitian ini berupa lagu Ebiet G Ade dalam album Perjalanan sebanyak 9 lagu. Lagu tersebut berjudul: 1. Berita Kepada Kawan; 2. Camelia; 3. Cintaku Kandas di Rerumputan; 4. Lagu Untuk Sebuah Nama; 5. Menjaring Matahari; 6. Ada Sisa-sisa Suara; 7. Asmara Suatu Ketika; 8. Sketsa Rembulan Emas; 9. Masih Ada Waktu

Pengumpulan data penelitian ini dilakukan dengan teknik pencatatan (Sugiyono: 2006 ). Teknik pencatatan diperlukan untuk mencatat data yang diperlukan setelah sebelumnya dilakukan pengamatan. Tahapan langkah-langkah pengumpulan data: 1) mempersiapkan segala sesuatu sebelum melakukan pengumpulan data, 2) mengamati lirik lagu Ebiet G Ade dalam album Perjalanan, 3) menandai kalimat-kalimat dalam lirik lagu Ebiet G Ade yang mencirikan metafora, 4) mencatat kalimat-kalimat dalam lirik lagu Ebiet G Ade yang terdapat metafora, kemudian memasukan dalam tabel data. Sedangkan pengalisisan data metafora dalam lirik lagu Ebiet G Ade menggunakan teknik analisis isi. Teknik analisis isi merupakan teknik sistematik untuk menganalisis isi pesan atau mengolah pesan (Burhan, 2004). Teknik ini digunakan untuk menggambarkan isi pesan pada makna kata yang mengalami perubahan makna dalam kalimat tulis bahasa iklan. Tahapan penganalisisan data :1) mencatat kalimat-kalimat dalam lirik lagu Ebiet G Ade yang terdapat metafora, kemudian memasukkan dalam tabel data, 2) mengalisis kalimat-kalimat dalam lirik lagu Ebiet $G$ Ade yang terdapat metafora, menghubungkannya dengan konteks lagu, 3) memaparkan hasil analisis metafora dalam lirik lagu Ebiet G. Ade secara keseluruhan, 5) menyimpulkan hasil analisis metafora dalam lirik lagu Ebiet G Ade

\section{HASIL PENELITIAN}

Deskripsi data ini memuat uraian temuan metafora dalam lirik lagu Ebiet G.Ade Album Perjalanan, yang berisi sembilan judul lagu, meliputi: Berita Kepada Kawan, Camelia, Titip Rindu Buat Ayah, Menjaring Matahari, Lagu Untuk Sebuah Nama, Sketsa Rembulan Emas, Masih Ada Waktu, dan Ada Sisa- Sisa Suara. Dari lirik lagu inilah dapat ditemukan data berupa kalimat yang terdapat kata atau frasa mengandung metafora.

Dari album Perjalanan Ebiet G. Ade, yang terdiri dari sembilan lagu ditemukan 40 metafora, yang dapat dirinci sebagai berikut:1) lagu Berita Kepada Kawan terdapat delapan metafora, 2) lagu Camelia terdapat delapan metafora, 3) lagu Titip Rindu Buat Ayah terdapat tiga metafora, 4) lagu Menjaring Matahari terdapat enam metafora, 5) lagu Untuk Sebuah Nama terdapat satu metafora, 6) lagu Cintaku Kandas Di Rerumputan terdapat enam metafora, 7) lagu Sketsa Rembulan Emas terdapat enam metafora, 8) lagu Masih Ada Waktu terdapat satu metafora, 9) lagu Ada Sisa-Sisa Suara terdapat satu metafora.

Temuan penelitian mengenai penggunaan metafora dalam lirik lagu Ebiet G.Ade dalam album Perjalanan, dapat dilihat dalam tabel berikut:

Tabel 1

Judul Lagu: Berita Kepada Kawan

\begin{tabular}{llll}
\hline No & \multicolumn{1}{c}{ Kutipan } & Kata (Frasa) Metafora & \multicolumn{1}{c}{ Letak } \\
\hline 1 & $\begin{array}{l}\text { Banyak cerita yang mestinya kau } \\
\text { saksikan, di tanah kering bebatuan. }\end{array}$ & Tanah kering bebatuan & Bait kesatu larik keempat \\
\hline 2 & $\begin{array}{l}\text { Tubuhku terguncang dihempas batu } \\
\text { jalanan. }\end{array}$ & Batu jalanan & Bait kedua larik pertama \\
\hline 3 & Gembala kecil menangis sedih & Gembala kecil & Bait kedua larik keempat \\
\hline 4 & Sesampainya di laut. & Laut & Bait keempat larik pertama \\
\hline 5 & $\begin{array}{l}\text { Kepada karang, kepada ombak, } \\
\text { kepada matahari. }\end{array}$ & Karang & Bait keempat larik ketiga \\
\hline 6 & $\begin{array}{l}\text { Kepada karang, kepada ombak, } \\
\text { kepada matahari. }\end{array}$ & Ombak \\
\hline 7 & $\begin{array}{l}\text { Kepada karang, kepada ombak, } \\
\text { kepada matahari. }\end{array}$ & Matahari \\
\hline 8 & $\begin{array}{l}\text { Coba kita bertanya pada rumput yang } \\
\text { bergoyang. }\end{array}$ & Rumput & Bait kelima larik kedelapan \\
\hline
\end{tabular}


Tabel 2

Judul Lagu: Camelia

\begin{tabular}{llll}
\hline No & \multicolumn{1}{c}{ Kutipan } & Kata (Frasa) Metafora & \multicolumn{1}{c}{ Letak } \\
\hline 1 & Dia Camelia. & Camelia & Bait kesatu larik kesatu \\
\hline 2 & Puisi dan pelitamu & Puisi & Bait kesatu larik kedua \\
\hline 3 & Puisi dan pelitamu & Pelita & Bait kesatu larik kedua \\
\hline 4 & $\begin{array}{l}\text { Kau sejuk seperti titik embun yang } \\
\text { membasahi daun jambu }\end{array}$ & Embun & Bait kedua larik kesatu \\
\hline 5 & Sayap-sayapmu kecil lincah berkeping & Sayap & Bait kedua larik ketiga \\
\hline 6 & Terbang mencari tiang sampan & Tiang Sampan & Bait kedua larik kelima \\
\hline 7 & Datang untuk hati yang kering dan sepi & Hati yang kering & Bait ketiga larik kelima \\
\hline 8 & Agar bersemi lagi & Bersemi & Bait ketiga larik keenam \\
\hline
\end{tabular}

Tabel 3

Judul Lagu: Titip Rindu Buat Ayah

\begin{tabular}{llll}
\hline No & \multicolumn{1}{c}{ Kutipan } & Kata (Frasa) Metafora & \multicolumn{1}{c}{ Letak } \\
\hline 1 & $\begin{array}{l}\text { Engkau telah mengerti hitam dan } \\
\text { merah jalan ini }\end{array}$ & Hitam & Bait kedua larik kesatu \\
\hline 2 & $\begin{array}{l}\text { Engkau telah mengerti hitam dan } \\
\text { merah jalan ini }\end{array}$ & Merah & Bait kedua larik kesatu \\
\hline 3 & Untuk menuai padi milik kita & Menuai Padi & Bait ketiga larik ketiga \\
\hline
\end{tabular}

Tabel 4

Judul Lagu: Menjaring Matahari

\begin{tabular}{llll}
\hline No & Kutipan & Kata (Frasa) Metafora & Letak \\
\hline 1 & Menjaring Matahari & Menjaring Matahari & Judul \\
\hline 2 & $\begin{array}{l}\text { Kabut, sengajakah Engkau } \\
\text { mewakili pikiranku }\end{array}$ & Kabut & Bait pertama larik pertama \\
\hline 3 & $\begin{array}{l}\text { Hitam, hitam pekat menyelimuti } \\
\text { matahari }\end{array}$ & Hitam & Bait pertama larik kedua \\
\hline 4 & $\begin{array}{l}\text { Mendung, benarkah pertanda akan } \\
\text { turun hujan }\end{array}$ & Mendung & Bait kedua larik kesatu \\
\hline 5 & $\begin{array}{l}\text { Mendung, benarkah pertanda akan } \\
\text { turun hujan }\end{array}$ & Hujan & Bait kedua larik kesatu \\
6. & Roda zaman menggilas kita & Roda Zaman & Bait ketiga larik kesatu \\
\hline
\end{tabular}

Tabel 5

Judul Lagu: Lagu Untuk Sebuah Nama

\begin{tabular}{llll}
\hline No & \multicolumn{1}{c}{ Kutipan } & Kata (Frasa) Metafora & Letak \\
\hline 1 & $\begin{array}{l}\text { Sedang musik pun manis } \\
\text { kudengar }\end{array}$ & Manis Kudengar & Bait kesatu larik kedua \\
\hline
\end{tabular}

Tabel 6

Judul Lagu: Cintaku Kandas di Rerumputan

\begin{tabular}{llll}
\hline No & \multicolumn{1}{c}{ Kutipan } & Kata (Frasa) Metafora & \multicolumn{1}{c}{ Letak } \\
\hline 1 & Cintaku Kandas di Rerumputan & Rerumputan & Judul \\
\hline 2 & Berpita jingga, sepatu hitam & Berpita jingga & Bait kesatu larik ketiga \\
\hline 3 & Berpita jingga, sepatu hitam & Sepatu Hitam & Bait kesatu larik ketiga \\
\hline
\end{tabular}




\begin{tabular}{llll}
\hline 4 & Dalam lingkaran membisu & Lingkaran & Bait ketiga larik kedua \\
\hline 5 & Iblis manakah yang merasuk & Iblis & Bait ketiga larik keempat \\
\hline 6 & Lembut memanggil namaku & Lembut Memanggil & Bait keempat larik keempat \\
\hline
\end{tabular}

\section{Tabel 7}

Judul Lagu: Sketsa Rembulan Emas

\begin{tabular}{llll}
\hline No & \multicolumn{1}{c}{ Kutipan } & \multicolumn{1}{c}{ Kata (Frasa) Metafora } & \multicolumn{1}{c}{ Letak } \\
\hline 1 & Sketsa Rembulan Emas & Rembulan Emas & Judul \\
\hline 2 & Angin malamdi laut pun terdiam & Angin Malam di Laut & Bait pertama larik kedua \\
\hline 3 & Menguak jendela hatimu & Jendela Hati & Bait ketiga larik keenam \\
\hline 4 & Merah hitam tanah kami & Merah Hitam & Bait keempat larik kedua \\
\hline 5 & Pucat pasi wajah bumi & Wajah Bumi & Bait keempat larik ketiga \\
\hline 6 & Tolong, arahkan mata pedang & Mata Pedang & Bait keempat larik keempat \\
\hline
\end{tabular}

Tabel 8

Judul Lagu: Masih Ada Waktu

\begin{tabular}{lllc}
\hline No & \multicolumn{1}{c}{ Kutipan } & Kata (Frasa) Metafora & Letak \\
\hline 1 & $\begin{array}{l}\text { Mengumpulkan bekal perjalanan } \\
\text { abadi }\end{array}$ & Perjalanan Abadi & Bait kesatu lirik keempat \\
\hline
\end{tabular}

\section{Tabel 9 \\ Judul Lagu: Ada Sisa-Sisa Suara}

\begin{tabular}{lllc}
\hline No & \multicolumn{1}{c}{ Kutipan } & Kata (Frasa) Metafora & Letak \\
\hline 1 & $\begin{array}{l}\text { Bertarung serentak bergumul bola- } \\
\text { bola hati }\end{array}$ & Bola-bola Hati & Bait kedua larik ketiga \\
\hline
\end{tabular}

\section{PEMBAHASAN}

Berdasarkan temuan metafora pada lirik lagu Ebiet G.Ade dalam album Perjalanan yang terdiri dari 9 judul lagu, terdapat 40 metafora, dapat dirinci sebagai berikut:1) lagu Berita Kepada Kawan terdapat delapan metafora, 2) lagu Camelia terdapat delapan metafora, 3) lagu Titip Rindu Buat Ayah terdapat tiga metafora, 4) lagu Menjaring Matahari terdapat enam metafora, 5) lagu Untuk Sebuah Nama terdapat satu metafora, 6) lagu Cintaku Kandas Di Rerumputan terdapat enam metafora, 7) lagu Sketsa Rembulan Emas terdapat enam metafora, 8) lagu Masih Ada Waktu terdapat satu metafora, 9) lagu Ada Sisa-Sisa Suara terdapat satu metafora.

Penggunaan metaforanya terdapat dua macam makna, yaitu makna kias dan makna yang dimaksudkan. Makna yang dimaksudkan diungkapkan lewat serangkaian kata yang dapat diterapkan bersama lambang kias. Temuan penelitian telah dipaparkan dalam tabel. Berikut ini akan dideskripsikan secara menyeluruh mengenai metafora dalam lirik syair lagu Ebiet G.Ade album Perjalanan.

1. Dalam lagu pertama berjudul Berita Kepada Kawan terdapat 8 metafora (data: 1-8), terdiri dari:tanah kering berbatuan, batu jalanan, gembala kecil, laut, karang, ombak, matahari, dan rumput.

Sesuai dengan judul lagunya Berita Kepada Kawan, metafora yang didapatkan dari lagu tersebut banyak mengandung makna yang berkaitan dengan sesuatu yang dirasakan dan dijumpaii oleh seseorang dalam kesendiriannya menempuh sebuah perjalanan. Di antara apa yang telah dialami dalam perjalanan, seseorang tersebut menjumpai warga yang terkena musibah. Akhirnya banyak pertanyaan-pertanyaan yang muncul dalam dirinya tentang kejadian tersebut. Hal tersebut menginspirasi terciptanya lirik lagu yang indah dan sangat menyentuh dengan menggunakan ungkapan metafora.. Tanah kering berbatuan mengarah kepada wilayah yang begitu kering dan penuh batu, dan bisa saja menandakan sesuatu yang negatif

( diceriterakan terjadi suatu bencana). Batu Jalanan, sebuah metafora,yang mengiaskan perjalanan yang dilakukan amat berat, bahkan batu jalanan pun ikut jadi kendala dan tak terhitung jumlahnya. Gembala Kecil, merupakan pilihan kata yang sering digunakan oleh kaum Nasrani. Tuhan adalah gembala yang baik atau gembala yang besar Jika gembala besar 
adalah Tuhan, maka gembala kecil memetaforakan manusia. Laut, memaknakan akhir dari sebuah perjalanan, sebab laut tak bisa dilewati dengan berjalan kaki. Karang dikiaskan sebagai sesuatu yang kokoh karena karang sekeras batu. Ombak hanya ada di laut, akan cepat hilang dan datang/muncul kembali berganti dengan yang baru. Matahari, sumber panas atau yang memberi energi. Lirik "Kepada karang, kepada ombak, kepada matahari" mengandung makna sosok tokoh yang kokoh (para pemimpin), tokoh yang dating dan hilang (para relawan), dan sosok yang memberi energy (pemimpin spoiritual). Rumput merupakan metafora terakhir di lagu ini, memaknakan tumbuhan yang tumbuh liar di jalanan dan tidak terurus tapi bisa jadi tempat bertanya setelah tidak mendapatkan jawaban dari siapapun.

2. Dalam lagu kedua berjudul CAMELIA, terdapat 8 metafora( data: 1-8) terdiri dari: Camelia, Puisi, Pelita, Embun, Sayap, Tiang Sampan, Hati yang kering, dan Bersemi.

Delapan metafora dalam lagu ini memperindah lagu dan memperkuat makna lagunya. Penggunaan metafora Camellia untuk menyimbolkan nama seorang gadis serupa bunga Camellia, Puisi merupakan perlambangan susunan kata indah yang akhirnya membentuk nama Camellia itu sendiri. Pelita merupakan simbol dari seorang Camelia yang mampu memberikan penerang, kehangatan, dan penunjuk jalan dalam kegelapan. Embun, melambangkan kesejukan yang mampu diberikan Camelia, Sayap, merupakan bagian tubuh burung yang bisa membuat dirinya terbang. Manusia ingin terbang seperti burung dengan sayapnya.Tiyang Sampan merupakan sebuah sandaran yang memetaforakan seorang Camelia yang bebas pada hakikatnya mencari sandaran. Hati yang kering merupakan kiasan untuk kehampaan, kehidupan yang tidak bergairah. Kering diartikan ketiadaan air yang merupakan sumber kehidupan, Tanpa air maka orang tidak bergairah dalam kehidupannya. Bersemi mempunyai makna bertunas/tumbuh kembali. Bersemi memetaforakan Camelia terhadap penulis lagu yang tadinya hati penulis kering menjadi bersemi/ bersemangat kembali.

3. Dalam lagu ketiga berjudul TITIP RINDU BUAT AYAH, terdapat 3 metafora (.data 1-3), terdiri dari kata . hitam, merah, dan menuai padi.

Pada lagu ini tidak begitu banyak menggunakan metafora. .Dalam kalimat Engkau telah mengerti hitam dan merah jalan ini. Hitam merupakan metafora sisi gelap kehidupan manusia (ayah), sedangkan merah melambangkan keberanian untuk tetap berjuang meskipun menemukan kesedihan. Menuai padi dmemetaforakan kebahagiaan yang dulu pernah diangankan seseorang

4 .Dalam lagu keempat berjudul MENJARING MATAHARI, terdapat 6 metafora (data 1-6), terdiri dari menjaring matahari, kabut, hitam, mendung, hujan, roda zaman.

Frasa menjaring matahari yang dijadikan judul lagu merupakan metafora dari menangkap atau memerangkap orang-orang yang ada disekitarnya. Kabut dalam lagu ini menggambarkan kekelaman yang menutupi pikiran jernih. Seperti dalam lirik Sengajakah Engkau(kabut) mewakili pikiranku..Hitam bermakna negatif yaitu pikiran atau keadaan kotor. Mendung bukanlah warna yang kesemuanya hitam, tetapi kelabu kehitaman sehingga dapat memaknakan memberikan sebuah harapan. Hujan dimaknai dapat mengubah sesuatu yang kering menjadi basah. Mewujudkan harapkan adanya perubahan keadaan yang lebih baik.

5. Dalam lagu kelima berjudul LAGU UNTUK SEBUAH NAMA, terdapat 1 metafora. ( data: 1), yaitu kata manis kudengar.

Manis kudengar merupakan satu-satunya metafora yang terdapat dalam lirik lagu ini, menggambarkan sebuah musik yang didengar terasa manis. Penggunaan frasa manis kudengar mengalihkan indera satu ke indera lain. Manis biasanya dicecap oleh lidah sebagai indera pengecap beralih ke indera pendengaran.

6. Dalam lagu keenam berjudul CINTAKU KANDAS DI RERUMPUTAN terdapat 6 metafora (data 1-6), terdiri dari rerumputan, berpita jingga, sepatu hitam, lingkaran, iblis, dan lembut memanggil.

Cintaku kandas di rerumputan. merupakan salah satu lirik lagu yang memanfaatkan metafora. Rerumputan diambil dari makna rumput yang tumbuh liar dan tidak terurus. Rerumputan merupakan suatu hal yang tidak terurus. Dalam konteks lagu ini bermakna cinta yang berakhir. Berpita jingga bermakna angan angan baik mengenai seorang gadis yang dicintainya. Sepatu hitam bermakna yang sebaliknya dari berpita jingga. Kalau pita jingga menggambarkan anganangan baik mengenai seseorang, kalau sepatu hitam bermakna angan-angan buruk. Lingkaran bermakna penjara yang tiada ujung, sesuai dengan konteks lirik lagu Aku merasa terjebak dalam lingkaran membisu. Iblis dimaknakan makhluk jahat, yang bisa mempengaruhi keputusan seseorang. Walaupun itu salah tetapi tetap dilakukannya,,,Lembut memanggil 
termasuk metafora yang mengalihkan indera satu ke indera lain. Lembut termasuk indera perasa tapi dialihkan ke indera pendengaran.

7. Dalam lagu ketuju berjudul SKETSA REMBULAN EMAS terdapat 6 metafora. ( data: 1-6) terdiri dari rembulan emas, angin malam di laut,jendela hati, merah hitam, wajah bumi, dan mata pedang.

Rembulan Emas bermakna rembulan yang berkilau seperti emas atau bulan purnama menggambarkan keadaan yang sedang berada di puncak. Angin malam di Laut. Angin yang bertiup di laut pada waktu malam hari dengan kencang. Jendela hati, hati bagaikan jendela yang bisa dibuka dan ditutup. Merah hitam, merah seperti merah putih dalam warna bendera bermakna keberanian, sedang hitam itu gelap atau pahitnya kehidupan.. Jadi merah hitam bermakna:harus semangat berjuang meski menemukan kesedihan di dalamnya. Wajah bumi, bumi seolah- olah memiliki wajah, sesuai dengan lirik Pucat Pasi Wajah Bumi. Mata pedang, dimaknakan sebagai doa dan harapan yang dapat menghujam ke sasaran yang dituju.

8. Dalam lagu kedelapan berjudul MASIH ADA WAKTU terdapat 1 metafora. ( data 1), yaitu perjalanan abadi.

Metafora perjalanan abadi terdapat dalam bait kesatu larik keempat mengumpulkan bekal perjalanan abadi . Perjalanan abadi bermakna perjalanan abadi dikehidupan selanjutnya.

9. Dalam lagu kesembilan berjudul ADA SISA-SISA SUARA, terdapat 1 metafora. ( data: 1), yaitu Bola-bola hati.

Bola-bola hati merupakan satu-satunya metafora yang terdapat dalam lirik lagu Ada Sisa-Sisa Suara yang merupakan lagu terakhir dari Album Perjalanan Ebiet G.Ade. Bola-bola hati bermakna hati seperti bola yang terus bergulir dan tidak bisa dikendalikan.

Berdasarkan hasil analisis di atas, lagu Ebiet G. Ade dalam album Perjalanan, metafora digunakan untuk menciptakan nilai keindahan. Metafora banyak diungkapkan dengan bahasa puitis yang rumit sehingga sulit dimaknai, menggunakan bahasa kias, persamaan, perbandingan untuk menggambarkan suatu objek. Penggambaran kondisi kebenaran diungkapkan secara tidak langsung atau melalui objek lain, mempersamakan satu objek dengan objek lain. Analogi-analogi juga digunakan untuk memahami arti non literal yang ada dalam lirik lagu.

Pada lagu- lagunya, Ebiet G. Ade menggunakan metafora untuk menggambarkan pemikiran dan pemaknaan tentang cinta dan percintaan antar insan dalam kehidupan manusia yang meliputi kebahagiaan, kesedihan, angan-angan. Penggunaan metafora juga untuk menggambaran tentang manusia, hidup, dan kehidupan meliputi perasaan, penderitaan, kesedihan, keresahan. Metafora digunakan juga untuk menggambarkan gejala alam, kehidupan masyarakat, gejolak sosial yang ada dalam masyarakat, penggambaran tentang dunia. Penggambaran hubungan manusia dengan Tuhan juga banyak diungkapkan dalam bentuk metafora-metafora yang rumit.

Pesan-pesan yang disampaikan dalam lagu Ebiet G. Ade yang terungkap melalui penggunaan metafora bahwa di dalam kehidupan manusia ada cinta. Cinta dapat membawa kebahagiaan, kesedihan, bahkan mungkin cinta hanya di angan-angan. Dalam menjalin sebuah hubungan cinta, kita harus mau berkorban, serta memegang norma-norma. Selain itu pesan bahwa manusia harus sabar, tabah, berjuang, semangat dalam menjalani kehidupan. Dalam kehidupan, manusia harus berperilaku baik, saling menolong, manusia juga harus menjaga alam Selain itu terdapat pesan yang disampaikan untuk pemimpin-pemimpin dunia, jadilah pemimpin yang bijaksana dan dapat menciptakan perdamaian. Terakhir, dalam hubungannya manusia dengan Tuhan bahwa kita harus taat dalam beribadah agar mendapat karunia dari Allah. Amin.

Manusia dalam hidupnya banyak sekali memperoleh pengalaman, Kadang seseorang menghubungkan sesuatu yang dialaminya sebagai fakta empirik belaka, adapula yang menghubungkan dengan sesuatu yang ada dalam dirinya. Bagaimana cara mengekspresikan perasaannya melalui bahasa, juga berbeda beda. Namun untuk lebih mengekpresikan perasaan yang akan diungkapkan, pada umumnya digunakanlah metafora. Adakalanya metafora dimanfaatkan pula sebagai sentuhan estetik yang dituangkan dalam sebuah tulisan, yang sering dijumpai dalam lirik lagu.

Metafora merupakan bahan kajian materi dalam pembelajaran Semantik Bahasa Indonesia. Dari hasil analisis metafora dalam lirik lagu Ebiet G.Ade dalam album Perjalanan, ditemukan 40 metafora. Dikaitkan dengan pembelajaran semantik, hasil analisis metafora tersebut menunjukkan bahwa melalui syair lagu kita dapat belajar metafora. Dengan demikian bahan ajar bisa bervariasi dan pembelajaran tidak mengalami kejenuhan. Dengan mengetahui penggunaan metafora dalam lirik lagu Ebiet G.Ade. maka kita dapat memahami pemikiran, makna, dan pesan yang diungkapkan, sehingga dapat memperkaya kosa kata. 
Berdasarkan pada pemahaman tersebut, maka lirik lagu Ebiet G. Ade layak dijadikan bahan pembelajaran Semantik Bahasa Indonesia. Dikatakan layak karena dilihat dari sudut pandang Semantik, lirik lagu Ebiet G.Ade banyak ditemukan penggunaan metafora..

\section{SIMPULAN}

Berdasarkan hasil penelitian penggunaan metafora dalam lirik lagu Ebiet G. Ade, Album Perjalanan serta implikasinya dalam pembelajaran Semantik Bahasa Indonesia dapat disimpulkan sebagai berikut:

1. Pada lagu Ebiet G.Ade album Perjalanan terdapat sembilan lagu. Dalam sembilan lagu tersebut ditemukan 40 metafora pada lirik lagunya, dapat dirinci sebagai berikut:1) lagu Berita Kepada Kawan terdapat delapan metafora, 2) lagu Camelia terdapat delapan metafora, 3) lagu Titip Rindu Buat Ayah terdapat tiga metafora, 4) lagu Menjaring Matahari terdapat enam metafora, 5) lagu Untuk Sebuah Nama terdapat satu metafora, 6) lagu Cintaku Kandas Di Rerumputan terdapat enam metafora, 7) lagu Sketsa Rembulan Emas terdapat enam metafora, 8) lagu Masih Ada Waktu terdapat satu metafora, 9) lagu Ada Sisa-Sisa Suara terdapat satu metafora.

Untuk menciptakan nilai keindahan dan puitis pada lirik lagu, Ebiet G. Ade menggunakan bahasa kias, persamaan, perbandingan untuk menggambarkan suatu objek yang diungkapkan dalam bentuk metafora.. Analogi-analogi juga digunakan untuk memahami arti non literal yang ada dalam lirik lagu. Penggunaan metafora juga untuk menggambarkan pemikiran dan pemaknaan tentang cinta dan percintaan antar insan dalam kehidupan manusia yang meliputi kebahagiaan, kesedihan, angan-angan. Penggambaran tentang manusia, hidup, dan kehidupan meliputi perasaan, penderitaan, kesedihan, keresahan juga diungkapkan melalui metafora. Selain itu,metafora juga untuk menggambarkan gejala alam, kehidupan masyarakat, gejolak sosial yang ada dalam masyarakat dan penggambaran tentang dunia, dan hubungan manusia dengan Tuhan.

2. Penggunaan metafora pada lirik lagu Ebiet $G$. Ade dapat diimplikasikan pada pembelajaran Semantik Bahasa Indonesia karena metafora termasuk dalam kajian Semantik. Dalam lirik lagu Ebiet G.Ade album Perjalanan ditemukan 40 metafora yang dapat dikaji untuk menambah pengetahuan tentang kosa kata dan tentang makna. Selain itu, pembelajaran semantik tentang metafora melalui syair lagu dapat mengembangkan pemikiran, makna, dan pesan dalam syair lagu. . Pembelajaran menjadi bervariasi sehingga lebih menarik minat kita untuk belajar Semantik.

\section{DAFTAR PUSTAKA}

Bungin, Burhan. 2004. Metodologi Penelitian Kualitatif. Jakarta: Raja Gafindo Persada Chaer, Abdul. 2009. Pengantar Semantik Bahasa. Indonesia Jakarta: Rineka Cipta.

Effendi, S. 1995. Panduan Berbahasa Indonesia dengan Baik dan Benar. Jakarta: Pustaka Jaya.

Keraf, Gorys. 2000. Diksi dan Gaya Bahasa. Jakarta: Gramedia Pustaka Utama

Jaszczolt. K.M. 2002. Semantics and Pragmatics; Meaning in Languge and Discourse. Longman. London

Awe, Mooko. 2007. Fals. Yogyakarta: Ombak

Parera. 2004.Teori Semantik. Jakarta:Erlangga.

Samsuri. 1985. Tata Kalimat Bahasa Indonesia. Malang: Sastra Herdaya.

Sugiyono. 2006. Metode Penelitian Pendidikan. Bandung: Alfabeta.

Supriyanto, 2011. Teguh. Kajian Stilistika dalam Prosa. Yogyakarta: Elmatera.

Tarigan, Henri Guntur. 2013. .Pengajaran Gaya Bahasa.. Bandung: Angka.

Verhaar. 2015. Azas-azas Linguistik Umum. Yogyakarta: UGM Press 